\title{
This is Rape Culture, Ladies and Gentlemen
}

\section{Victoria Kuttainen}

\author{
James Cook University
}

\begin{abstract}
${ }^{66} \mathrm{~W}$ hen I see a girl," he said, "all alone in a pack of boys -" He looked at me and then back across the college quadrangle where he gestured to the girl walking with four young men, "-that always makes me nervous."
\end{abstract}

Clem was gay. He was a grad student in English Literature. We tutored Freshman Composition together and shared an office. We'd both been staring out the window vacantly, stymied by the pile of mindless essays we were set to mark.

"Let's go outside," he said. I knew he wanted to keep an eye on the group, and I followed him out into the cold for a cigarette and a brain break. I watched his nicotine-stained fingers roll the tobacco. He wore fingerless gloves in the stark Canadian winter. The digits were chafed red, and his cuticles looked sore and frayed. He rolled and tapped expertly, then offered me the first puff.

"It never got me in too much trouble," I told him, exhaling a curl of smoke.

"Too much?" he pried. I looked into his face as he sucked inward. His cheeks were sallow and his complexion was mottled red.

"I guess I was that girl," I confessed. "I never really thought about it before. I was that girl who preferred male company."

"And why was that?" he said, adding a little pointedly, "I bet male company preferred you."

He continued to keep his gaze fixed on the gang of boys and the lone girl amongst them. "Boy, boy, boy, boy, girl," he counted. "Four to one."

"What is it that bothers you?" I asked, following his gaze. They weren't first-year students. Something in their body language made that clear. They had their bearings and knew what they wanted. Probably sophomores, heading toward the Student Union Building. The student bar had a regular happy hour.

"I'd be surprised if you could tell me about a case where it ended well," he said. 
The sun was low in the sky and our exhaled breath mingled and hung in the frosty air like special effects from a smoke machine. Clem and his drama, I thought.

"Well - " I began, and then paused as we watched the clutch of students regroup and change direction suddenly, heading toward the bus depot at the edge of the Student Union Building.

"They were my drinking buddies the year after high school," I told him. "I wouldn't say it was perfectly innocent," I inhaled and exhaled for dramatic pause, "but then nothing is when you are eighteen, confused, think you know everything, and alcohol is involved."

Clem laughed and took his eyes off the group only momentarily to cast me a dramatic piercing stare.

"Pray tell, where did you meet these said drinking buddies?" he asked.

"Through Hamish," I said.

Clem cocked an eyebrow. "Hamish?" he repeated, mockingly. "That's an asshole's name."

"Well, as it turned out-" I choked in laughter.

"What did I tell you?" Clem said. An outburst echoed through the air and hung in the space between us and the students across the quadrangle. Clem squinted and thrust his neck forward in their direction, adding a flourish of increased scrutiny to his surveillance. The fluorescent streetlights flickered on, and his gaze lingered over the group. He turned his attention back to me, momentarily satisfied by his stock-taking. The girl had a long blonde ponytail. She was attractive.

Clem read my thoughts. "They always are," he said.

"What?" I queried, a little impatient by now with his knowing, wizened tone and his drama.

"I saw you looking at her," he said. "They always are attractive. The lone girl." He added, with a tone that said, Duh.

"Yeah," I continued, "Hamish was an asshole." I remembered the first 'date' we had. It was our second week in a row skipping school in our spare study period. We were supposed to be in the library studying for our Grade 11 Biology mid-term, but he had lured me back to his place for what was meant to be a home-based study session. Another friend was supposed to meet us there, but never showed. Hamish's mom had recently gone back to work after his dad had died, and the house was empty. He forced himself on me and afterward I sucked his dick in the shower, as if that would somehow make us even. "There goes my virginity," I shrugged. I remember looking at all the Bible-saying magnets his mom had arranged on the fridge door in their kitchen, trying to piece together whether she'd discovered religion after her 
husband's death, or before. Their house didn't feel religious. I wondered if maybe it was an AA thing: God grant me the serenity to make it through all this bullshit and hold a job down to raise my boys alone. I hated thinking about all this again, and skipped right over in the telling.

"He had a friend, Derek," I said, "who turned out to be okay."

"Can you wait here a minute?" Clem interrupted as he butted out the stub we had finished. "I'm out of tobacco but I have a pack of cigarettes back in the office." He touched my arm and caught my eye. "Just hold that thought."

"No, we can go in," I said. It was almost dark now. I had a bus to catch, a kid at home with a babysitter, and the group of students at the bus stop had satisfied us both by now, I figured, as being innocuous.

"No," Clem insisted. "I want to hear this story. And keep an eye on those kids, okay?" he added. "I'll be five secs. You'll still catch your bus on time."

I watched the sophomores across the quadrangle, loafing at the bus stop. No buses came and there were no other people in sight. A fog was rising from the slick pavement as a chill set into the air. The rain had lifted just before nightfall and there were still a few last rays of sun lingering, streaking violent purple and deep red across the sky. The fluorescent light pooled in puddles between their bodies. They had lit up and slumped with their heads down and their hands punched into their coat pockets, not in a clump, but each separate and alone. There was space between them but they'd come together momentarily and then detach. They looked to be sharing a joint.

"Hey," Clem announced, as he drew up beside me again, and flicked his silver lighter, the kind you got engraved from a tobacconist's shop. He passed me a lit cigarette as he took another out of the golden foil package for himself. Always the gentleman.

"So, there was this other guy, Derek, you were saying," Clem cued me and then quickly interjected: "Those students are smoking spliff," as his eyes had rested over them again. "At least that will make them a little more subdued," he added with not a little irony in his voice.

"Yeah," I said. "Derek was okay. Though I guess it didn't start out that way. Hamish lured me back to some buddies' place. I think they were dope dealers. We met Derek there. They all got high and watched pornos and jacked off together." I said matter-of-factly.

"So these were nice boys," Clem observed. "Just as I predicted."

"They were pretty harmless," I added, sarcastically gesturing to the sophomores at across the commons at the bus stop. "They were stoned."

"Really?" prodded Clem, "What do you expect they wanted out of you in their little porno pit?" 
I laughed it off, then added, "Whatever they thought, if they thought anything at all, it didn't really interest me. The place was a disaster. I ended up cleaning the whole apartment from top to bottom. Like I was their fricking maid. I couldn't stand the filth."

"Interesting," said Clem.

"Not so much," I said. "It's the common denominator of bachelor potheads who watch porn. When they introduced me to their other friend Jack he used to laugh about it. The mess, that is. He called his apartment The Dagobah System."

Clem looked at me, inquiringly.

"You know: Yoda's swamp, from Star Wars."

"Yes, I know the place," he said impatiently. His pointed tone made it clear that he hadn't been querying the movie reference, but my sanity.

The kids decamped from the bus stop, and started making in the direction of the Student Union Building from whence they'd came.

"There's not much to tell," I said. "You want a story, and all I've got is a scenario."

"So how did it end?" he asked. "Badly I guess."

"Hmm," I mused. "You might say I was lucky. " Clem arched his eyebrow at me again while inhaling on his cigarette. "As it turns out," I added, to emphasise that I understood my own stupidity and reckless risk-taking behaviour.

"There were a lot of nights of drinking, Clem." I said. "Much of it is a blur."

He continued to smoke in silence, watching the kids scuffing their feet along the slick pavement, trudging slowly toward the bar. He was waiting for some kind of ending, so I gave him one.

"Well, the last thing I really remember," I said, "is this one time when I was the driver."

"Sure, Bonnie and Clyde," said Clem slyly. "The girl is always the getaway driver. It's built into the script. A value-add."

"I guess," I said, unsure of the accuracy of the film reference and making a mental note to myself to follow up. Are the girls always the designated driver? Did Bonnie do the driving for Clyde? 
"Hey," he said, "I think we should call campus security. This just doesn't feel right to me." The youths were still lingering around the Student Union Building, without going in. They looked aimless, but not threatening, to me.

"Clem, I'm telling you, it's harmless. They're just kids, and not every lone girl hanging with guys is grist for a gang bang. You've watched too many movies."

"Alright," he concluded, after a long silence, as I observed the red ring around his cigaretteend flare and dull again through two inhales.

"Clem, it's getting cold. The last bus is going soon and I have to be on it."

"Not 'til you tell me how this ends," he insisted.

"Fine," I said. "I was the driver. We'd been smoking hash. We were stoned out of our trees, and someone hatched this plan to drive down to the river. We picked up a flat of beer and headed down the valley taking quiet, country roads. We passed maybe one car the whole way. I was completely paranoid and was driving like $30 \mathrm{k}$ an hour. The guys thought it was hilarious until headlights picked us up and started tailing us from behind, really close. The slower I started going, the slower the car behind us went too. I even pulled over for a while, expecting the car to pass. And it didn't. It pulled over too. We were completely freaking out."

"Was it cops?" asked Clem, looking genuinely worried for me, and partly hopeful that the gig was up and I was saved from myself and others, criminal record or no.

"We weren't sure," I continued. Clem beckoned toward the kids with his head, his hands balled in his coat pockets. They seemed to be walking toward us now. They had spotted us against the Admin Building and it appeared to have registered that we had been watching them.

"Go on," he urged me, as if signalling that I better finish up because we had a bogey on our right.

"So I just kept driving," I explained, "Trying my hardest to actually accelerate to the speed limit. It was the hardest 60 kilometres an hour I ever did. The car kept tailing us, and as we turned in toward the dark parking lot at the river's entrance, the car turned too. It was a totally deserted place. Just us and the car, so we kind of figured whoever was on our tail, this was it: end game. I was freaking that the boys had a six-pack of open alcohol between them, and I knew that was an illegal offence. We parked and they opened up the car doors and started pouring out the beer and trying to stash the cans, and then the sirens of the tail car lit up. It was cops."

It was just us and the sophomores now. The campus was completely deserted this bleak Friday night. They continued to slouch toward us. 
"So what did they do?" asked Clem. "What happened?"

"It was just one cop," I said. "No partner or anything. He shone his torch into our car and asked if we'd been drinking. I said, 'No, Officer.' Of course. And actually I hadn't. My saving grace was that he didn't ask me if l'd been smoking drugs."

"He shone his torch at each one of us, holding it steady on our faces, one by one, and counted from me, the driver, to the front seat passenger and then the back: 'Girl, boy, boy, boy, boy.' Then he asked us to get out of the car, and made us empty all the alcohol. We had to give him all our names. And then he went back to the squad car with my licence and registration for what seemed like an eternity."

Clem was shaking his head at me, and making disapproving clucking noises.

"He was back in the squad car for as much as twenty minutes, before coming back. I guess he was just giving us a scare, and time to sober up. Because then he shone his torch right at me, holding out my paperwork, and asked me really, really earnestly if I was okay. I said yes. And he said, 'Okay."'

"And then he explained that he was going to let us off on a warning this one time. But he said, 'You guys are really lucky, you know. You could have hurt someone out here, if you didn't have a responsible driver, and it's an illegal offence to have open alcohol in an operational vehicle."”

"Fuck me," Clem said. He nodded toward the group of students that was now only about 100 metres away now.

"When we got back in the car," I finished, "it was a really sombre mood. And you know, I don't remember if that it was the actual end of me hanging out with them." I tried to think back and recall. "But if it wasn't," I concluded, "it was definitely the beginning of the end."

I laughed nervously, and Clem looked at me, laughing too, still shaking his head. And then said, part judgment, part compassion, part warning: "You were lucky, you know."

The group of sophomores scaled the three steps that led to the Admin Building and the girl with the blonde ponytail led the pack.

She broke away from the boys, who hung back in a huddle with their heads down and their faces concealed inside their hoodies. She was the only one who made eye contact, and she looked me right in the face, as she asked "Is this building open?" Explaining only: "The Student Union Building is all closed up tonight."

I was a little confused. "Um, no." I responded, "I mean, we have a key. Our office is in here. But everyone's gone home. It's all closed up for the weekend now. There's nothing in there." 
"Can we help you?" asked Clem.

The boys continued to hang silently in the background, a few bright eyes glinting out from the caverns of their sweatshirt hoods. It was unclear if they'd put her up to something or if she was bothered by them. I looked into her face. She had such clear, youthful skin, and big, stoned eyes.

"No, that's okay," she said, confidently. And that was it. She strode off into the night.

We watched the boys turn tail and follow her.

"Clem," I assured him, "She's okay. Geez. They're just walking back in the direction of the residential college. Don't be so paranoid. I have to go."

Clem didn't take his eyes off the group of students as we walked back toward the building and I unlocked the door to collect our things and head home.

He was still unsettled, by the students, by my story, and well, probably-because it was Clem - by life. "You were lucky," he said again, and kissed me on the cheek to say goodbye. He reeked of cigarette smoke and I felt the stubble of his unshaven face graze mine.

The students were just vague blobs in the dusky fog when we last saw them. I'm not sure what made Clem more nervous in the end: the girl in the pack, or the boys.

But we left it at that. "Good night Clem," I said, "You don't need to come with me to the bus stop."

Those eyebrows arched again. It was as if he didn't believe a word I ever said about anything. "I'm totally fine," I said, assertively. "Please go home."

He blinked at me and stared, and then turned on foot toward his place nearby.

I made my way alone to the dark bus stop. And as I sat in the cold waiting for the Number 11, I felt a lump in my throat, and swallowed hard. 


\section{Research Statement}

\section{Research Background}

$\mathrm{T}$ he term "rape culture" first emerged from feminist scholarship in the 1970s in attempts to deconstruct "rape myths" (such as prevailing notions about "stranger rape," a stereotype of sexual assault that had predominated to such an extent that it hampered acknowledgment of more common forms of sexual assault and violence). Investigators of rape culture sought to expose the pervasiveness of sexual violence in some societies, in which rape is so widespread as to be normalised due to accepted social attitudes. Whilst some identify North American society as a generalised rape culture, others point to college campuses and fraternity houses as intensified sites of predatory sexual behaviour. In these milieus and others, misogynistic attitudes toward sex and gender are so pervasive that they are normalised.

In 2017, the Broderick Review, named for the former Sex Discrimination Commissioner Elizabeth Broderick AO, was engaged by James Cook University in North Queensland, Australia to comprehensively review the University's sexual harassment and sexual assault policies and procedures, as well as the University's culture. The Report made the recommendation that "[s]uccessful and sustainable change depends on strong and courageous leadership that reverberates through the institution" (2017, p.16). In response to this recommendation, leaders have emerged in the university community bravely sharing stories of their own experiences and helping draw attention to the pervasiveness of sexual harassment and assault on university campuses.

The Broderick Review Report arrived in the wake of the Australian Human Rights Commission report (2017) on the nature and extent of sexual assault and harassment at Australian universities more broadly. More than 1800 people made submissions to the Commission sharing their stories about the way their lives have been impacted by their experiences in ways that suggested Australian universities have only just begun to identify the scope and nature of these issues. Yet there exists little understanding of the nature and extent of "rape culture," especially in Australia, and the term has rarely been applied to Australian university campuses.

In fact, despite the outpouring of testimonies about sexual harassment and assault in response to the allegations against Harvey Weinstein and broader revelations of normalised predatory sexual behaviour amongst "the old boys club" of Hollywood, discussions about rape culture seem to have stalled. The 2017 \#metoo campaign on social media gestured to the magnitude of the problem of sexual violence against women on a global scale, yet despite their acknowledgement of the large-scale problem, the media largely remains fixated on the high profile cases of a few individual victims or perpetrators and on the nuances between different kinds of sexual violence. As American Senator Kirsten Gillibrand has recently remarked in response to the flood 
of allegations against Senator Al Franken: "I think when we start having to talk about the differences between sexual assault and sexual harassment and unwanted groping you are having the wrong conversation. You need to draw a line in the sand and say none of it is O.K. None of it is acceptable"' (Goldmacher, 2017).

Research from first person interviews that were part of some of the early investigations into rape culture (such as Koss 1988; or Kilpatrick, Edmunds, \& Seymour, 1992) uncovered a broad continuum of sexual aggression in which up to a quarter of respondents had experienced forced sex acts, most often by acquaintances; when these numbers are included within the statistical count of sexual assault, the problem is of a horrifying magnitude which calls for serious, sensitive, and complex conversations and analyses. Yet, the concept of "rape culture" has long occupied a precarious position in relation to the treatment of rape in the legal system, medical system, and the mainstream media, and is a polarising concept subject to public and scholarly debate. For instance, Roiphe (1993) and Hoff Sommers (2012) have questioned the validity of broadening the definition of rape to include respondents who do not even identify their own experience in those terms.

\section{Research Contribution}

"This is Rape Culture, Ladies and Gentlemen" uses the affordances offered by multiperspectival short fiction and thick description to re-centre attention on first-person experience and the "taken-for-granted" complexities of everyday life that are at the heart of rape culture. It attempts to highlight the "everydayness" of rape culture which makes rape almost invisible within a normalised milieu of predatory sexual behaviour. In this, it draws on sociological theories of the practices of everyday life (Lefebvre, 1947/1991; de Certeau, 1974/1984; Felski, 1999), in which commonplace situations, mundane routines, and normal behaviours-that are usually taken for granted-are focalised. My story takes place on a college campus in North America, and involves a pivotal conversation between a homosexual man and a heterosexual woman that draws attention to the different ways in which rape is visible or invisible depending on characters' (and readers') positioning in relation to hegemonic social norms.

The title of the story is an intertextual reference to a well-known short story in the eponymous collection This way for the gas, ladies and gentlemen (1948/1980) by Polish writer Tadeusz Borowski, a survivor of Auschwitz who later took his own life, at the age of twenty-eight. In Borowski's story, a character trapped within a prison camp laconically reports on the daily minutia of his everyday routine in which violence has been normalised, and in which it is treated casually if not indifferently. Through drawing this connection with Borowski's work, "This is rape culture, ladies and gentlemen," suggests that some aspects of rape culture are shared by the scenario of accepted and normalised violence Borowski outlines as a prisoner of, and as a prison camp worker within, the Nazi regime. In particular, the milieu of rape culture and life under the Nazi regime share a normalisation of violence in which deliberate acts of brutality have become routinised and all-pervasive in ways that potentially acclimatise 
participants to the nightmarish logic of its ontological assumptions. It is suggested that these shared features may contribute to some aspects of the acceptance and invisibility of cultures of violence, to those who are positioned within them.

Critical theorists Theodor Adorno and Max Horkheimer (1944/1972a) posited that the development of violent fascism was a logical extension of industrial capitalism, in which scientific knowledge and modern systems of production and exchange had become so abstracted from human values, relationships, and organic communities that the very promise of progress or liberation that these systems offered also helped create a world in which people might willingly swallow brutal ideology and engage in deliberate acts of inhuman behaviour. Adorno and Horkheimer (1944/1972b) also suggested in their chapter of the same name, that the "culture industry" of industrialised entertainment comprising of the distractions of popular culture was a tool in that kept the public docile, and primed the masses to accept the deceptions of dehumanising industrial capitalism. Despite the outdated elitist assumptions underpinning Adorno and Horkheimer's critique of the "culture industry" that have been deservedly called into question, some of their insights seem more relevant now than ever. In particular, the implication of the film industry, in the context of late capitalism, in large-scale practices of gross dehumanisation now appear-in light of the Weinstein scandal and the flood of allegations of sexual assaults and harassment in Hollywood-especially prescient and even somewhat uncanny.

Hollywood has long been under fire from feminists as being a tool of domination by a few rich men who control the industry and prime the public to accept as normative their limited worldview - one that is typically white, privileged, American, and misogynistic. In her famous essay, "Visual pleasure and narrative cinema" (1975), Laura Mulvey, for example, noted that women on screen are often, if not always, the object of visual consumption rather than the subject whose perspective focalises the film; the implication of Mulvey's work is that the filmic "gaze" normalises an ocularcentric culture in which women are conditioned to look at themselves through the eyes of men. Alison Bechdel, in a somewhat more recent example, invented the simple "Bechdel Test" (1986), which most films continue to fail; instead of presenting the visual perspective of women, Bechdel's test is an auditory one. To pass, a film only needs to have at least two female characters who speak to each other about a subject other than men. Bechdel and Mulvey are just two examples of feminist critics who identified ways that mainstream Hollywood films perpetuate gender inequality.

The female character in this story regularly benchmarks details in her life against obscure film scenarios, which she only partially questions. The laconic tone she adopts, in which nothing much matters, is suggested in the stock phrase introducing acts for entertainment, "Ladies and Gentlemen." The assumption that the masculine, heterosexual worldview is normative is also implied in that stock phrase. Here, Clem's homosexuality is a key aspect of the story as he helps the narrator see from another perspective, and to adopt other potential ways to focalise and understand her 
experience, within a broader scene of normalised sexual violence that pervades the campus atmosphere. Adorno and Horkheimer observed that the promise of modern science to liberate people from ignorance and mind-numbing work was contradicted as its technologised effects actually primed them to accept a world of dehumanisation, which popular culture also numbed them to. Similarly, the promise of the modern university to provide the hope of future enlightenment is also broken and dashed in this dark, shadowy world that these students inhabit as "lurkers" looking for a fix. Here the parallels between the kind of society that produces Nazi genocide and the kind of society that becomes an all-encompassing misogynistic rape culture intersect in a vision of a dehumanising reality that people "willingly swallow."

Yet the alternative perspective offered by Clem forces the female narrator to remember and relive repressed experiences which she "skip[s] over in the telling." As yet another demand for her to perform in ways that satisfy the desires of others, her reluctant willingness suggests her hesitation to comply with his desires to shape her story into some kind of morality tale. By Clem's series of questions and subtle judgements or attitudes, it is as if she is compelled to fit her complex experience into his worldview, to satisfy the shape of a narrative he views life conforming to, even if it is one that positions her experience in ways that might allow her to express it as validating the sexual violence she has endured. Her wish to keep aspects of her story to herself, and to free herself from his paternalistic though friendly and "gentlemanly" protection means that she takes risks that potentially position her as free but do so in dubious circumstances, in which freedom comes at a cost, to herself and others.

\section{Research Contribution}

The story responds to Buchwald, Fletcher, and Roth's call in Transforming a rape culture (2005) for new approaches to draw attention to sexual violence and its origins in everyday culture. It does so by seeking to refocus attention on rape culture in sensitive ways that might productively explore the complexity of normalised and socially pervasive sexual violence. Rather than engaging in polarised and often intellectualised debates about rape, it seeks through the empathetic and multiperspectival affordances of fiction to open up the validating potential of first-person experience. Further, through the deployment of a first-person narrative focusing on embodied experience, it seeks to draw on the lived testimony of personal experience that has powerfully emerged out of the flood of personal stories that have been shared in the aftermath of the Weinstein revelations. As a story that explores multiple points of view, it is structured around seeing and perspective, hoping to make the invisible visible, and to allow for a complex, empathetic appraisal of various points of view. In this it draws also from the motif of the doppelgänger that structures a story like Conrad's "The secret sharer" (1910). In watching a young woman being watched by a protective gaze, when the female narrator looks her in the eyes, she sees her other self: a young wide-eyed woman whose freedom comes at potentially dangerous cost, and whom she has potentially overlooked or failed to protect. 
The heavily ironic intonation of the phrase, "you were lucky," repeated throughout the story, nods to the irony undergirding the scenario of freedom in a culture of entrapment. In Alice Sebold's memoir of rape, Lucky (1999), she is regularly told by the police whom she reports her rape to that she was "lucky" because by "only" being raped, she may have escaped being murdered. The character in this story is similarly told she is "lucky," repeatedly. But unlike Sebold who resists this description, she laconically applies it to herself. Further, unlike Sebold who reports her rape, the narrator in this story does not report or potentially even acknowledge to herself that she was victim of a sexual assault at a young age, an aspect of her experience that no doubt shaped her induction into a worldview in which rape culture is accepted and widespread. The story attempts to raise questions about a culture in which to "get lucky" might on the one hand mean freedom, whilst on the other hand, to "be lucky" might not describe the experience of being a woman at all.

Finally, this story aims to focus the Australian conversation on the issue and extent of "rape culture," particularly on university campuses, in the wake of the Broderick Review and the Human Rights Commission Report. In so doing, this story aims to address "Principle Three" of the Broderick Recommendation that "Education underpins behaviour change to create a safe, respectful, and inclusive culture" (2017, p. 20).

\section{References}

Adorno, T., \& Horkheimer, M. (1972a). Dialectics of enlightenment. (J. Cumming, Trans.). New York: Herder and Herder. (Original work published 1944).

Adorno, T., \& Horkheimer, M. (1972b). The culture industry: Enlightenment as mass deception. In T. Adorno and M. Horkheimer. Dialectics of enlightenment. (J. Cumming, Trans.). New York: Herder and Herder. (Original work published 1944).

Australian Human Rights Commission. (2017). Change the course: National report on sexual assault and sexual harassment at Australian universities.

Retrieved from https://www.humanrights.gov.au/our-work/sexdiscrimination/publications/change-course-national-report-sexual-assault-andsexual

Bechdel, A. (1986). Dykes to watch out for. Ithaka, NY: Firebrand.

Borowski, T. (1980). This way for the gas, ladies and gentlemen. (B. Vedder, Trans.). London: Penguin. (Original work published 1948).

Broderick, E. (2017). The Broderick review report: Effectively responding to sexual harassment and sexual assault at James Cook University. Townsville, Australia: James Cook University. Retrieved from https://www.jcu.edu.au/safety-and-wellbeing/broderick-review/BroderickReview-Report-JCU-2017.pdf

Buchwald, E., Fletcher, P., \& Roth, M. (2005). Editors' preface. In E. Buchwald, P. Fletcher, \& M. Roth (Eds.). Transforming a rape culture (2nd ed.). Minneapolis, Minnesota: Milkweed Editions 
Conrad, J. (1910). The secret sharer [Project Gutenberg]. Retrieved from http://www.gutenberg.org/files/220/220-h/220-h.htm

de Certeau, M. (1984). The practice of everyday life. (S. Rendall, Trans.). Berkeley: University of California Press. (Original work published in 1974).

Felski, R. (1999). The invention of everyday life. Cool moves: a journal of culture/theory/politics. 39, pp.15-31.

Goldmacher, S. (2017, December 6). On sexual misconduct, Gillibrand keeps herself at the fore. The New York Times. Retrieved from https://www.nytimes.com/

Hoff Sommers, C. (2012). Researching the 'rape culture' of America. Retrieved from http://www.leaderu.com/real/ri9502/sommers.html

Kilpatrick, D.G., Edmunds, C., \& Seymour, A. (1992). Rape in America: A report to the nation. Charleston, SC: National Victim Center \& the Crime Victims Research and Treatment Center, Medical University of South Carolina.

Koss, M. (1988). Hidden rape: Sexual aggression and victimization in a national sample of students in higher education. In A, Burgess, (Ed.). Rape and sexual assault, (Vol. 2.) New York: Garland.

Lefebvre, H. (1991). The critique of everyday life. (J. Moore, Trans.). London, Verso. (Original work published 1947).

Mulvey, L. (1975). Visual pleasure and narrative cinema. Screen. 16(3), 6-18.

Roiphe, K. (1993). The morning after: Sex, fear, and feminism. Boston: Little, Brown.

Sebold, A. (1999). Lucky. New York, NY: Scribner. 